\title{
Соном-Ишийн Дашщэвэл
}

Монгол улсын гуравдахь хөршийн бодлого дахь Зүүн Өмнөд Азийн Холбоо (АСЕАН)-ны орон зай.

Хэдийбээр олон улсын харилцааны тогтолцоон дахь шилжилтийн үе хараахан дуусаагүй, дэлхийн шинэ дэг журам төгс төлөвшин тогтоогүй “олон төрлийн хүчин зүйлээс хамаарал бүхий тодорхой бус шинж чанартай үе” хэмээн үзэж(1) байгаа ч гэсэн сүүлийн жилүүдэд дэлхийн тавцанд том гүрнүүдийн геополитикийн байр суурь, улам бүр тодорхой болж Орос, Хятад зэрэг хүчирхэг, тоталитар маягийн улс гүрнүүд ба өрнийн либерализмын хооронд геополитикийн ан цав үүсч эхэлснийг дэлхийн стратеги судлаачид цохон тэмдэглэсээр байна(2). Хүйтэн дайны дараа дэлхий ертөнцийн геополитик , үзэл суртал ойртон нэгдэж, эв нэгдэл мандан бадарна гэсэн бидний ойлголт хориод жилийн дараа өөрчлөгдөж байгааг сая мэдэрч эхэлж байна. Иймд бид одооноос гадаад улс төрийн бодлогодоо ул суурьтай хандаж, дэлхийн бодлогыг тодорхойлогч их гүрнүүдийн геополитикийн зөрчилдөөн дунд өөрийгөө хэрхэн авч гарах, үндэсний эрх ашгаа хамгаалахын тулд тэдгээрийн ашиг сонирхлын тэнцвэрийг хэрхин бий болгох талаар одооноос нухацтай судалж үйл явцын өрнөлийг урьдчилан харж байх шаардлагатай болжээ. Өөрөөр хэлбэл бидний эдийн засгийн болон улс төрийн аюулгүй байдал нэн эмзэг байгаа өнөө үед аюулгүй байдал хийгээд ардчилсан сонголтод учрах сорилтуудыг урьдчилан тооцож хэрхин түүнээс зайлсхийж тойрч гарах вэ гэсэн суурь асуултуудад хариу өгөх ёстой юм. Энэ нь аль нэг эвсэлд нэгдэх гэсэн ойлголт биш бөгөөд Ази - Номхон Далайн бүс нутгийн томоохон улс гүрнүүд, эдийн засаг улс төрийн нэгдлүүдийн эрх ашгийн тэнцвэрийг бий болгож аюулгүй байдал болон ардчилсан сонголтоо баталгаажуулах асуудалтай холбоотой билээ.

Монгол улс хоёр том хөршийн дунд арал мэт оршдог. Орос, Хятад хоёр хөрш маань эрх мэдлийн төлөө барууны либерал гүрнүүдтэй харгалдан сөрөх байдал нь тодорсоор. Бас дээр нь тэд ардчилалыг “социалист маягийн ардчилал”, “Нийгмийн ардчилал” гэх мэтээр өөрийнхөөрөө тайлбарлаж үзэл суртлын зааг ялгааг тодруулсаар байна. Монголчууд бид “хүмүүнлэг” хэмээх тодотголтой 
ардчиллыг сонгоод зүүн тийш хандсан нийгмийн “социал демократ” маягийн бодлого хэрэгжүүлж эхэлсэн нь Монголын хөгжлийн тодорхой үе шатанд нийцэж байгаа боловч цаашдаа дэлхий нийтээр хүлээн зөвшөөрөгдсөн либерал ардчиллыг үнэт зүйлээ болгосон ардчилсан улс болохын төлөө явж байгаа улс хэмээн ойлгож болно.

Зүүн Өмнөд Азийн улс орнуудын нэг хэсэг нь барууны либерал, нөгөө хэсэг нь тоталитар, бас зарим нь уламжлалт засаглалтай боловч бүс нутгийн орнуудын ихэнхи нь либерал үзэлд тулгуурласан барууны хөгжлийг чиг баримжаагаа болгосон улс орнууд билээ. ГагцхүҮ хүний эрх, эрх чөлөөний талаарх зарим үзэл санаа нь нэг хэсэгтээ өөрийн гэсэн өнгө төрхийг хадгалах төлөв бий. Гэхдээ бүс нутгийнхны ихэнх нь улс төрийн чөлөөт ардчилал, зах зээлийн эдийн засгийн нээлттэй байдлыг эрхэмлэж, аюулгүй байдлын хувьд АНУ, Япон зэрэг хөгжингүй орнуудын өмөг түшигт илүү найддаг. Энэ нь олон улсын тэнхлэг хэлбэржин, нэгэнт ҮҮссэн ан цавууд нэлээд тодорч байгаа өнөө үед Монгол, АСЕАН-ы орнуудын хоёр талын улс төрийн харилцааг ойржуу байлгах нэгэн хүчин зүйл болоод байна.

Сүүлийн үед Зүүн Өмнөд Азийн бүс нутаг дахь АНУ- Хятадын стратегийн өрсөлдөөн гүнзгийрч байгаа нь АСЕАН-ы бүлгийг улам нягтруулж Ази-Номхон далайн бүс дахь их гүрнүүдийн нөлөөг тэнцвэржүүлэхэд басхүү мэрийлт гаргахад хүргэв. Хятад ба АНУ-ын гео-стратегийн бодлого тэдгээр орнуудын аль алинд нь чухал байр эзэлж байгаа тул бусад түншүүдтэй харилцахдаа мөн л тэрхүҮ тэнцвэрт сөрөг нөлөө үзүүлэхгүйг эрмэлзсээр байна. Хятадаас болгоомжилж АНУ, Япон, Европын Холбоо, Австралитай харилцааг өргөжүүлэхийн хамт Оросын Холбооны улс, Энэтхэгтэй харилцахдаа басхүҮ том гүрнүүдийн гео-стратегийн сонирхолыг бүс нутагтаа тэнцвэржүүлэхэд ашиглаж байх жишээтэй.

Либерал ардчиллын эрх ашгийнхан цэнхэр, үндэсний дарангуй буюу жинхэнэ ардчиллыг засварлаж өрнийн либерализмтай геостратеги, ашиг сонирхолын хувьд сөрөхийг санаархагчдынх улаан гэвэл иймэрхүү зураг төсөөлөгдөнө.

Ази Номхон далайн газрын зураг

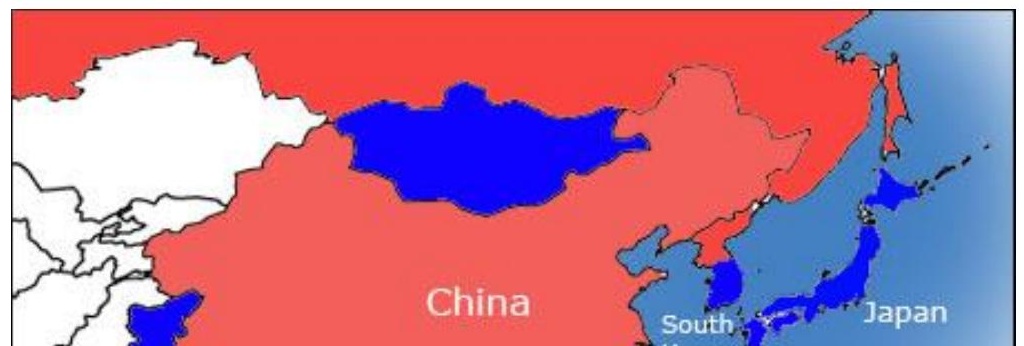


Бид одоохондоо илт цэнхрийнхэн билээ. Алс нь ямар өнгө рүҮ явах нь тодорхойгүй. Учир нь Шанхайн тавд бүслэгдсэн. Тал талаас булангийн шахалтад орсон мэт тун таагүй байршилтай байна. ГагцхүҮ гурав дахь хөршийн том ашиг сонирхлуудыг өөрийн нутагт байршуулах ажлыг цаг алдалгүй хийвэл одооныхоо байр сууринд нэлээд тэсч үлдэх магадлалтай билээ. Эс тэгвээс эдийн засаг, улс төрийн шахаанд бууж өгөөд хоёр хөршийн аль нэгний хавсарга эдийн засаг болоод зогсохгүй улс төрийн шууд хараат болох ойрхон байна. Ардчилал ч аандаа шаргалтан бүдгэрнэ. Улсаа аварья гэвэл уул уурхайгаа хүртэл одооноос бодлоготой ашиглаж хөрөнгө оруулагчийг оновчтой хуваарилах хэрэгтэй ажээ.

Сүүлийн үед манай улсын нутаг дэвсгэр дээр ашигт малтмалын үлэмж нөөц бүхий ордуудыг ашиглах явдал эрчимтэй болсонтой холбогдон, мөн уул уурхайн бүтээгдэхүүний эрэлт хэрэгцээ дэлхийн хэмжээнд нэмэгдсэн зэрэгтэй уялдан их гүрнүүдийн геополитик, гео-эдийн засгийн өрсөлдөөн идэвхжих болов. Манай улс хөрш хоёр орны аль нэгний эсвэл хоёулангийн геополитикийн үгсэлцээний шахалтанд ороход тун амархан бөгөөд улс төрийн дархлаа нэн эмзэг орны нэг. Тийм ч учраас юун түрүүнд хөрш хоёр их гүрэнтэйгээ адил тэнцвэртэй харилцааг эрхэмлэхийн зэрэгцээ гуравдахь хөршийн хүчин зүйлийг тулгуур болгохыг аюулгүйн болон эдийн засгийн бодлогодоо үндсэн чиг баримжаа болгодог билээ. Монгол улсын Гуравдахь хөршийн тухайд бид юуны өмнө АНУ, ЕХ, Япон, 
Энэтхэг, БНСУ, Турк зэрэг улсыг дурдсаар ирсэн(3). Гэтэл Ази-Номхон далайн бүс дахь АСЕАН-ы орнуудын эдийн засаг сүүлийн жилүүдэд амжилттай хөгжиж тэнд шинээр аж үйлдвэржсэн орнуудын тоо өсөн нэмэгдэж, Ази Номхон Далайн бүс нутгийн эдийн засгийн эрчимтэй хөгжлийн нэгэн төв болж олон улсын харилцаанд тэдгээрийн үзүүлэх жин нөлөө өссөөр байна. Манай улс ба АСЕАН-ы гишүүн орнуудын хооронд санал зөрөлдөөн, маргаантай асуудал байхгүй, аль аль нь харилцааг иж бүрэн хөгжүүлэх эрмэлзлэл төгс байдаг. Мөн бидний харилцаа улс төр, эдийн засаг, шинжлэх ухаан, соёл, боловсрол, байгаль хамгаалал, хүмүүнлэг, батлан хамгаaлах, аюулгүй байдлыг бүрэн хамрах хандлагатай байгаа гэх зэрэг хүчин зүйлийг тооцвол дэлхийн байдал нэлээд өөрчлөгдөж байгаа өнөө үед АСЕАН хэмээх улс төр, эдийн засгийн Холбоог гуравдахь хөршийн хэмжээнд авч Үзэхийг эрмэлзэх нь зүйтэй мэт.

Цаашид эдийн засгийн хамтын ажиллагааг өргөжүүлэх замаар АСЕАН-тай түншийн харилцааг бий болгох нь манай улсын олон тулгуурт бодлого, аюулгүй байдал, эдийн засгийн хөгжил дэвшлийн зорилгод нийцэх бөгөөд алс хэтдээ манай улсын эдийн засаг, улс төрийн аюулгүй байдлын хувьд их гүрнүүдтэй ашиг сонирхлын тэнцвэрийг бий болгоход стратегийн ач холбогдолтой билээ. Үүний анхны алхам нь АСЕАН-ы Найрамдал, Хамтын ажиллагааны Гэрээнд(2005 он) нэгдсэн явдал билээ. Бүс нутгийн интеграцид оновчтой байдлаар оролцох манай бодлогод хамгийн ойр нь Ази Номхон далайн бүс нутагт өрнөж буй Зүүн Азийн хамтын ажиллагаа (Зүүн Азийн чөлөөт худалдааны бүс (EAFTA), Зүүн Азийн Эдийн засгийн олон талт түншлэл (Comprehensive Economic Partnership for East Asia) бөгөөд үүнд оролцох бэлтгэлийг хангах явдал нэн тулгам болжээ. АСЕАН-ыг Зүүн Азийн хамтын ажиллагааны механизмын залуурыг атгагч хүч (as the driving force) хэмээн үзэж байгаа өнөө үед АСЕАН-д итгэл үзүүлэх, тэдэнтэй бүхий л талаар ойртон ойлголцож, хамтрахыг хичээх нь бүр ч чухал болоод байна. АCEAHы гадаад харилцаа нь 1/ Dialogue Partner (Яриа хэлцээний түнш), 2/ Sectoral Dialogue Partner, 3/ Development Partner, 4/ Special observer, 5/ guest гэх мэт олон түвшний статус буй тул үүнийг оновчтой сонгон ашиглах хэрэгтэй мэт.

Үүний тул юуны өмнө бизнесийн хүрээнийхэн, төрийн бус байгууллага, иргэд хоорондын харилцааны түвшинг дээшлүүлж бие биенээ танин мэдэх, 
бодлого зорилгоо ойлгон хүдэтгэж итгэлцлийг бэхжүүлэх, харилцааг эдийн засагжуулах чиглэлд түлхүү анхаарах нь чухал байна.

\section{Ашигласан материал}

1. Монгол Улсын гадаад бодлогын хөх ном. 2007-2011. УБ. 2011 он. 11-p тал

2. Роберт Каган. Түүх эргэн ирж мөрөөдөл төгссөн нь. УБ.2010.

3. Шинчлэн найруулсан Гадаад бодлогын үзэл баримтлал. УБ. 2011

4. John Stenbruner, The prospect of Cooperative Security, The Brookins Review, Winter 1988/89.

5. Pham Duc Thanh. Lien ket ASEAN trong thap nien dau the ky XXI. Hanoi, 2006. Tr.255.

6. Treaty of Amity and Cooperation in South East Asia, Bali, 24.II.1976.

7. Монгол улсын Үндэсний аюулгүй байдлын үзэл баримтлал /Шинэ/

8. Tran Dinh Thien.Lien ket kinh te ASEAN: Van de va trien vong /ACEAH-ы эдийн засгийн интеграци: Зарим асуудал ба хэтийн төлөв/. На Noi, 2005, tr.168.

9. Д.Тунгалаг Монгол улсын эдийн засгийн аюулгүй байдлыг хангах арга зам “Стратеги судлал” сэтгүүл 2007, 12 116-128-р тал

10. Б.Сувд “Эдийн засгийн өнөөгийн байдал ба бодлого” Стратеги судлал, $2008^{17}$, 107-р тал

$$
\mathrm{O} \mathrm{O} \text { o }
$$

